\title{
LBBB and High Afterload
}

Citation for published version (APA):

Prinzen, F. W., Willemen, E., \& Lumens, J. (2019). LBBB and High Afterload: A Dangerous Liaison? JACC-Cardiovascular Imaging, 12(6), 978-980. https://doi.org/10.1016/j.jcmg.2017.12.002

Document status and date:

Published: 01/06/2019

DOI:

10.1016/j.jcmg.2017.12.002

Document Version:

Publisher's PDF, also known as Version of record

Document license:

Taverne

\section{Please check the document version of this publication:}

- A submitted manuscript is the version of the article upon submission and before peer-review. There can be important differences between the submitted version and the official published version of record.

People interested in the research are advised to contact the author for the final version of the publication, or visit the DOI to the publisher's website.

- The final author version and the galley proof are versions of the publication after peer review.

- The final published version features the final layout of the paper including the volume, issue and page numbers.

Link to publication

\footnotetext{
General rights rights.

- You may freely distribute the URL identifying the publication in the public portal. please follow below link for the End User Agreement:

www.umlib.nl/taverne-license

Take down policy

If you believe that this document breaches copyright please contact us at:

repository@maastrichtuniversity.nl

providing details and we will investigate your claim.
}

Copyright and moral rights for the publications made accessible in the public portal are retained by the authors and/or other copyright owners and it is a condition of accessing publications that users recognise and abide by the legal requirements associated with these

- Users may download and print one copy of any publication from the public portal for the purpose of private study or research.

- You may not further distribute the material or use it for any profit-making activity or commercial gain

If the publication is distributed under the terms of Article $25 \mathrm{fa}$ of the Dutch Copyright Act, indicated by the "Taverne" license above, 


\section{LBBB and High Afterload}

\section{A Dangerous Liaison?*}

Frits W. Prinzen, PHD, Erik Willemen, MSc, Joost Lumens, $\mathrm{PHD}_{\mathrm{H}}$

L eft bundle branch block (LBBB) is rare in the general population ( $\sim .5 \%)$; however, LBBB is fairly common in patients with chronic heart failure $(\sim 25 \%)$ (1). These numbers indicate an association between LBBB and cardiovascular disease, including hypertension and heart failure (2). These associations have raised the question of what is cause and what is consequence. Half a century ago, it was commonly believed that newly acquired LBBB was a hallmark of advanced hypertensive or ischemic heart disease. On the other hand, Breithardt and Breithardt reviewed literature evidencing that LBBB could promote development of heart failure (3). The latter observations were substantiated 2 decades later in animal experiments, in which induction of LBBB in otherwise normal dogs led to ventricular dilatation, asymmetrical hypertrophy, and a reduction in left ventricular ejection fraction (LVEF) (4). More recently, studies in patients who developed LBBB after valve replacement procedures confirmed a causal relation between LBBB and mortality (5). Obviously, the success of cardiac resynchronization therapy, which acutely improves pump function by correction of (most of) the electrical disturbances, also strongly supports the negative functional consequences of LBBB (6).

In this issue of $i J A C C$, Aalen et al. (7) present a very elegant study in patients and dogs that demonstrates

*Editorials published in JACC: Cardiovascular Imaging reflect the views of the authors and do not necessarily represent the views of iJACC or the American College of Cardiology.

From the Departments of Physiology and Biomedical Engineering, Cardiovascular Research Institute Maastricht (CARIM), Maastricht University, Maastricht, the Netherlands. Financial support of studies was provided by an Eracosysmed grant (PUSHCART) to Dr. Prinzen and Dr. Lumens, HORIZON 2020 grants (737817 AXONE and 644798 CARDIS) to Dr. Prinzen, and a senior postdoc grant from the Dutch Heart Foundation (NHS-2015T082) to Dr. Lumens. Dr. Prinzen has received research grants from Medtronic, St. Jude Medical (Abbott), LivaNova, Biotronik, and EBR Systems. Dr. Lumens has served as a consultant for Medtronic. Dr. Willemen has reported that he has no relationships relevant to the contents of this paper to disclose. that hearts with LBBB are more sensitive to increased left ventricular (LV) afterload than normal hearts. In asymptomatic patients with LBBB, afterload was increased by handgrip exercise and arm-cuff inflation, whereas in dogs, afterload was increased in a more controlled way by aortic constriction. Although in normal subjects, increased afterload reduced LVEF only mildly (7\%), this reduction was more pronounced in LBBB patients (14\%). The dog experiments showed that in particular, septal stretch during the ejection phase deteriorated at high afterload. Both in humans and in dogs, increased afterload in the LBBB heart created a clockwise rotation of the septal pressure-length loop, which indicates negative ("wasted") work generated by the septum.

$$
\text { SEE PAGE } 967
$$

Therefore, this study adds important information to the above-mentioned discussion as to whether LBBB is the chicken or the egg in relation to heart failure and hypertension: maybe it is both! After all, if LBBB develops in hypertensive patients (whether caused by hypertension or not), it creates a disproportionately negative effect on pump function.

The strain measurements reported by Aalen et al. (7) provide insight into the mechanism by which LBBB and high afterload synergistically cause deterioration in LV pump function. We can speculate about the mechanism as to why the reduction in function is seen especially in the septum. After discovery of abnormal strain patterns in asynchronous hearts, it was noted that the explanation for worsening of pump function could be sought largely in the inherent property of myocardial cells called length-dependent activation (also known as the FrankStarling mechanism) (8). The earliest-activated region (the septum in LBBB) starts to contract and shorten early, thereby stretching the later-activated LV lateral wall. After electrical activation of the LV lateral wall, its contraction is strong because of its pre-stretch, and this augmented contraction forces the septal myocardium to be stretched, even though it is still 


\section{Synchronous}
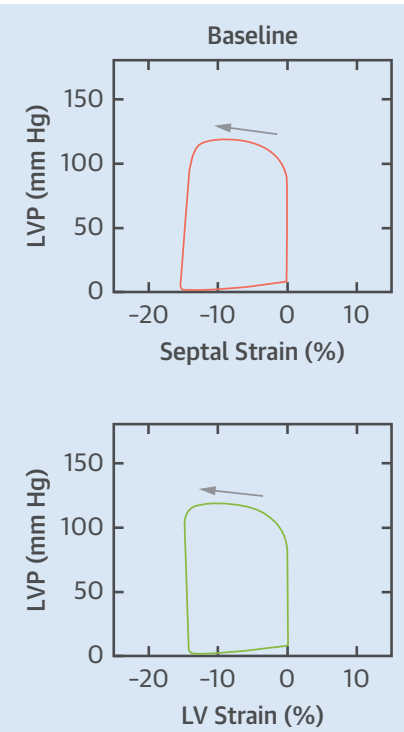
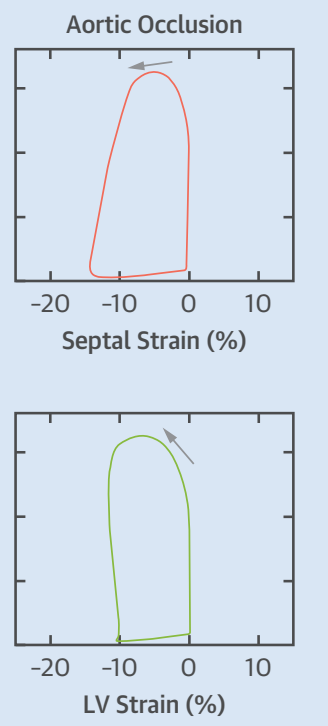

Dyssynchronous
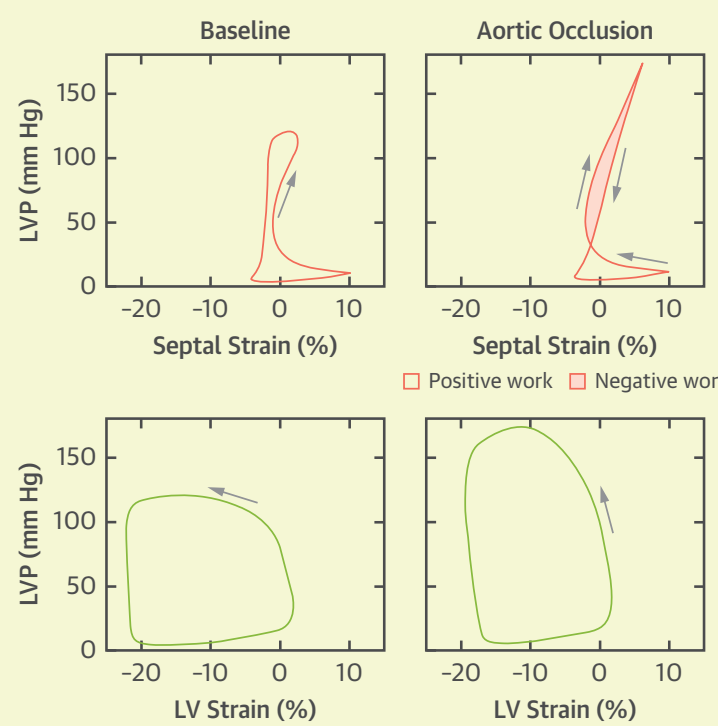

The MultiPatch version (10) was used for these simulations, with segments for the right ventricular, septal, and left ventricular (LV) wall. During synchronous activation, all segments were activated simultaneously, whereas for dyssynchrony, activation of the septum and LV wall was delayed by 15 and 60 ms, respectively, with respect to the right ventricle. LVP = left ventricular pressure.

actively generating force itself. There is evidence that the reduced systolic septal shortening (or even stretching) directly relates to the loss in pump function in dyssynchronous hearts (9).

A next step is to try to explain the further worsening of septal systolic function at high afterload. This could relate to the muscle property that contraction lasts longer when afterload is high. As a consequence, systolic stress in the LV lateral wall might remain elevated and could thereby stretch the septum more than when afterload is normal, thus amplifying mechanical dyscoordination.

Support for this idea comes from simulations we conducted in the CircAdapt computer program to simulate mechanics of the heart and circulation (10). Figure 1 illustrates pressure-strain loops that are comparable to the pressure-segment length loops in the paper by Aalen et al. (7). Increasing afterload hardly affects the loops in the synchronous heart, where simulating a mechanical activation delay in the LV free wall leads to a small pressure-strain loop that starts to turn clockwise when afterload is increased (simulated by partial aortic occlusion). Importantly, the CircAdapt model contains only a few elementary muscle properties, of which length-dependent activation is an important one. Therefore, it seems highly likely that the afterload hypersensitivity of LBBB hearts can be (largely) explained by a combination of basic muscle properties, interaction between ventricular walls, and the arterial afterload (Figure 1).

This likely explanation has at least 3 important clinical ramifications. First, quantification of mechanical dyssynchrony and discoordination is sensitive to afterload. This has also been shown to some extent by Park et al. (11), who used pneumatic leg compression and nitroglycerin administration to alter loading conditions. This implies that afterload is an important additional variable that should be known for proper interpretation of mechanical dyssynchrony data.

Second, because LVEF also shows afterload hypersensitivity in patients with LBBB, blood pressure should be taken into account when interpreting LVEF measurements. This seems especially important when decisions are made based on a cutoff value, such as $35 \%$ for device implantation.

Third, lowering the afterload in patients with LBBB might be even more favorable than in patients with narrow QRS complex and thus could be even more important for their proper treatment.

Of course, extrapolation of the results of this study to clinical care should be done with care. The study by 
Aalen et al. (7) only investigated patients with LBBB without heart failure symptoms. Further studies are required to determine whether the afterload hypersensitivity also occurs in failing LBBB hearts. It would be equally interesting to investigate whether application of cardiac resynchronization therapy in such patients would reduce the afterload hypersensitivity. If this were to happen acutely, it would provide strong support for the mechanism of afterload hypersensitivity proposed above.

Besides the small numbers of patients, a limitation of the study by Aalen et al. (7) is its acute design. There is no information on the potential long-term effects. However, the "natural" adaptation of the myocardium under these conditions is usually counterproductive: long-term dyssynchrony and pump failure induce dilatation and asymmetrical hypertrophy, complicated by adverse molecular changes $(4,12)$ and, through the cardiorenal axis, increased fluid maintenance. These all lead to further worsening of the condition of the patient. Therefore, the acute adverse effects of afterload could be amplified in the longer term. It is clearly of utmost importance to investigate this question in more detail.

In conclusion, the article by Aalen et al. (7) could be an important piece of the puzzle of understanding dyssynchronous heart failure, a piece that indicates that LBBB and LV pressure overload form a dangerous liaison, becoming hazardous at a much earlier stage than dangerous liaisons in fictional stories usually do.

ADDRESS FOR CORRESPONDENCE: Dr. Frits W. Prinzen, Department of Physiology, Maastricht University, P.O. Box 616, Maastricht, Limburg 6200 MD, Netherlands. E-mail: frits.prinzen@maastrichtuniversity.nl.
REFERENCES

1. Baldasseroni S, Opasich C, Gorini M, et al. on behalf of the Italian Network on Congestive Heart Failure Investigators. Left bundlebranch block is associated with increased 1 -year sudden and total mortality rate in 5517 outpatients with congestive heart failure: a report from the Italian network on congestive heart failure. Am Heart J 2002; 143:398-405.

2. Schneider JF, Thomas HE Jr., Kreger BE, McNamara PM, Kannel WB. Newly acquired left bundle branch block: the Framingham study. Ann Intern Med 1979;90:303-10.

3. Breithardt G, Breithardt OA. Left bundle branch block, an old-new entity. J Cardiovasc Transl Res 2012;5:107-16.

4. Vernooy $K$, Verbeek $X A$, Peschar $M$, et al. Left bundle branch block induces ventricular remodelling and functional septal hypoperfusion. Eur Heart J 2005:26:91-8.
5. Houthuizen P, Van Garsse LA, Poels TT, et al. Left bundle-branch block induced by transcatheter aortic valve implantation increases risk of death. Circulation 2012;126:720-8.

6. Lumens J, Ploux S, Strik M, et al. Comparative electromechanical and hemodynamic effects of left ventricular and biventricular pacing in dyssynchronous heart failure: electrical resynchronization versus left-right ventricular interaction. J Am Coll Cardiol 2013;62:2395-403.

7. Aalen J, Storsten P, Remme EW, et al. Afterload hypersensitivity in patients with left bundle branch block. J Am Coll Cardiol Img 2019;12:967-77.

8. Prinzen FW, Augustijn $\mathrm{CH}$, Arts $\mathrm{T}$, Allessie MA Reneman RS. Redistribution of myocardial fiber strain and blood flow by asynchronous activation. Am J Physiol 1990;259:H300-8.

9. De Boeck BW, Teske AJ, Meine M, et al. Septat rebound stretch reflects the functional substrate to cardiac resynchronization therapy and predicts volumetric and neurohormonal response. Eur J Heart Fail 2009:11:863-71.

10. Walmsley J, Arts T, Derval N, et al. Fast simulation of mechanical heterogeneity in the electrically asynchronous heart using the MultiPatch module. PLoS Comput Biol 2015;11:e1004284.

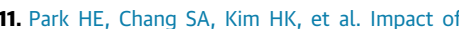
loading condition on the $2 \mathrm{D}$ speckle trackingderived left ventricular dyssynchrony index in nonischemic dilated cardiomyopathy. Circ Cardiovasc Imaging 2010;3:272-81.

12. Aiba $T$, Hesketh GG, Barth $A S$, et al. Electrophysiological consequences of dyssynchronous heart failure and its restoration by resynchronization therapy. Circulation 2009;119:1220-30.

KEY WORDS dyssynchrony, heart failure, hypertension, left bundle branch block, strain 